\title{
Lay Explanation of Poverty During the Pandemic in Hungary
}

\author{
Eszter Siposne Nandori \\ University of Miskolc, Miskolc, Hungary \\ stsneduni-miskolc.hu
}

\section{ABSTRACT}

The paper analyzes perceived causes of poverty in Borsod-Abaúj-Zemplén County, Hungary, one of the most disadvantaged areas of the country. Data collection was carried out in the second half of 2020 using consensus theory and the methods of systematic data collection. The aim of the research is to discover whether support for explanations which blame structural conditions is dominant in the public perception of poverty during the pandemic. From the research discussed it is clear that structural conditions are not dominant and that the poor are often seen as being themselves responsible for their unfavourable situation. The COVID-19 pandemic is not associated with a high support for the social type of lay explanations.

Keywords: Attributions for Poverty, Borsod-Abaúj-Zemplén County, COVID-19, Individual, Structural

Cite this article as: Nandori, E. S. (2021). Lay Explanation of Poverty During the Pandemic in Hungary. European Journal of Economics, 1(1), 34-40. https://doi.org/10.33422/eje.v1i1.45

\section{Introduction}

COVID-19 pandemic has had a significant effect on economic and social processes. Employment has fallen, while the number of registered job-seekers and the at-risk-of poverty rate have increased compared to the pre-crisis level. The effect of the pandemic on the lay explanation of poverty, however, is not clear.

The impact of the pandemic on the public perception of poverty is relevant because unusual social and/or economic strains can strengthen social beliefs making them temporarily dominant (Hunt, 1996; Kluegel and Smith, 1986; Lee et al., 1990; Marquis, 2020). The paper tests whether social types of poverty explanations are indeed dominant during the pandemic. The research is carried out in Borsod-Abaúj-Zemplén County, one of the most backward areas of Hungary.

This paper begins with s short review of the literature regarding lay explanations of poverty, followed by the applied methodology. Finally, the main findings and the conclusion is described.

\section{Lay Explanations of Poverty}

Reasons for poverty have been discussed by a great number of authors in literature. It was Feagin (1975) who first revealed that lay explanations of poverty can be grouped into three categories. Individualist reasons for poverty include cases when poverty is thought to be related to the attitude of the individual; structural causes of poverty are related to the society; while fatalist causes refer to impoverishment randomly or due to fate (Harper, 1996). In addition, attributions for poverty can be associated with financial situation (Williamson 1974) and ethnic origin (Hunt, 1996).

Furnham (1982) categorized the above described explanations of poverty as an individual blame type (like low willingness to work or laziness), a social blame type (like the lack of real 
social safety nets), and an individual fate type (like bad luck) of explanations. He added a social fate type (including cases like worldwide recession) to this categorization creating a two dimensional matrix of attributions for poverty. Van Oorschot and Halman (2000), Lepianka et al. (2009) and Kainu and Niemelä (2014) confirmed the four-type structure of poverty explanations.

There are differences in the importance of these categories across countries. In the AngloSaxon tradition, individualist beliefs predominate the public perception of poverty, while in continental Europe, societal explanations play an important role in the attributions for poverty (Kluegel et al., 1995). There are, however, some differences between Western Europe and postsocialist Europe (Kainu and Niemelä, 2014).

While social types of the lay explanations of poverty play a more important role in Western Europe, Eastern Europeans emphasize more individual blame types of poverty attributions (Kallio and Niemelä, 2014; Kreidl, 2000; Lepianka et al., 2009; van Oorschot and Halman, 2000). Across postsocialist European countries, there is a large variation of poverty explanations (Lepianka et al., 2009). Kainu and Niemelä (2014) concluded that social blame type of poverty explanations are the most popular in Ukraine, Lithuania, Slovenia, Hungary, Russia, and Latvia.

Less attention has been paid on the attributions for poverty specifically in Hungary. Kreidl (2000) revealed that no dominant ideology could be identified for poverty in Hungary in the 1990s. Habibov et al. (2017), by examining 24 post-communist countries, concluded that social type of poverty attributions were supported by more than half of the respondents in Hungary between 2006 and 2010.

Previous studies have shown that unusual social and/or economic strain can temporarily modify the public perception of poverty and structuralist beliefs can become dominant. Kluegel and Smith (1986) concluded that structuralist beliefs can temporarily become dominant. Hunt (1996) observed that structuralist views of poverty were more popular than individualistic beliefs under certain circumstances in the United States.

\section{Materials and Methods}

Based on the literature, I assume that structuralist beliefs of poverty are dominant during the unprecedented times of the COVID-19 pandemic. To test the hypothesis, primary data were collected using consensus theory and the methods of systematic data collection. Within the framework of consensus theory, a preliminary study is used to define the necessary sample size and the set of items relevant for the field of research. The minimum number of informants is a function of the average level of competence, the confidence level, and a minimum rate of questions to be classified correctly (Weller and Romney, 1988; Siposné Nándori, 2021b). The application of consensus theory requires meeting the following three assumptions:

- the average level of competence across the individuals shall be at least 0.5 ;

- the answers of the individuals shall be independent of each other;

- each question must deal with the same domain (Weller, 2007).

Preliminary study included interviews to elicit a list of lay explanations of poverty. To do so, the method of free listing was used. A total of 88 informants were asked from Borsod-AbaújZemplén County. Free listing elicited a total of 31 reasons for poverty, out of which nine were selected for further research taking into account the aim of the research and the frequency of the items mentioned in the free listing ${ }^{1}$ (de Munch and Sobo, 1988; Siposné Nándori, 2016). The attributions for poverty selected for further research can be seen in Table 1.

Table 1.

Perceived causes of poverty selected for further research based on free listing results (in alphabetical order)

Addiction Laziness Not enough working opportunity

${ }^{1}$ Items mentioned by fewer than 13 informants were excluded from the final research step. 


\begin{tabular}{lll}
\hline $\begin{array}{l}\text { Inability to economize } \\
\text { Large family }\end{array}$ & $\begin{array}{l}\text { Low education level } \\
\text { Low income level }\end{array}$ & $\begin{array}{l}\text { Poor health } \\
\text { Unemployment }\end{array}$ \\
\hline Source. own compilation & &
\end{tabular}

Taking into account that its three assumptions are met, consensus theory determines the necessary sample size for further research. The average level of competence is nearly 0.8. At least $99 \%$ of the questions should be classified correctly at the 0.99 confidence level, therefore the minimal number of informants is eight.

Table 2.

Sample decomposition based on the distribution of the population of Borsod-Abaúj-Zemplén County, Hungary

\begin{tabular}{lccc}
\hline & $\begin{array}{c}\text { Population } \\
(\mathbf{2 0 2 0})\end{array}$ & Sample size for free listing & Sample size for formal interviews \\
\hline Miskolc & 152,901 & 21 & 7 \\
Other towns & 220,436 & 30 & 10 \\
Villages & 263,727 & 37 & 12 \\
Total & $\mathbf{6 3 7 , 0 6 4}$ & $\mathbf{8 8}$ & $\mathbf{2 9}$ \\
\hline
\end{tabular}

Source. Siposné Nándori 2021a, p. 281.

Informants were then selected with the method of multistage cluster sampling with stratification (Maxfield and Babbie, 2009). The minimum number of informants from each settlement category was determined respecting the ratio of the population in the three categories (refer to Table 2). At last, a total of 29 persons were asked. Seven informants from the town of Miskolc, ten from other towns (Emőd), and twelve from communities (Radostyán and Karcsa) were selected (Siposné Nándori 2021a). Data were collected in the second half of 2020 .

In the final step of the data collection, the method of quicksort was used to rank the lay explanations of poverty from the one most often causing poverty to the one least often resulting in poverty. Attributions for poverty were written on cards and then the cards were randomized. In each interview, a card was selected as a standard and informants were asked to compare all other items to the standard and group them into two categories: attributions more often causing poverty than the standard and the ones that less often causes poverty than the standard. This process was repeated for each category until all poverty explanations were ordered (Weller and Romney, 1988; Siposné Nándori, 2021a).

The perceived causes of poverty were then grouped as individual, structural, and fatal. Next, Analysis of Variance was employed in SPSS program to discover if the three groups of poverty attributions are rated differently.

\section{Results}

Nine main reasons for poverty were mentioned by the informants (Figure 1). The top perceived reason was 'addiction', followed by 'low education level' and 'inability to economize'. Almost half of the perceived causes of poverty ('laziness', referring to the low willingness to work, 'unemployment', 'low income level', and 'not enough working opportunity') refer to labour market disadvantages. 


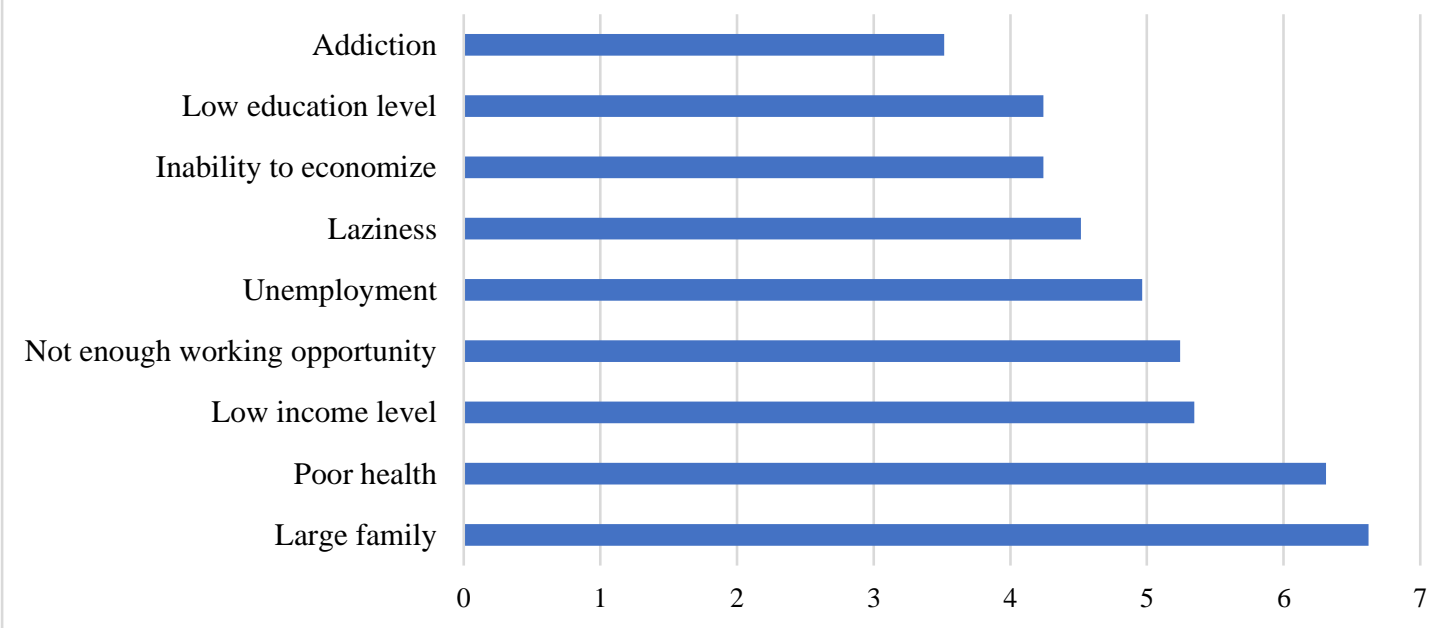

Figure 1. Rank order of the perceived causes of poverty (score 1 refers to the cause most often mentioned) Source. own compilation

Certain causes of poverty mentioned by the informants can be grouped as individual, social, or fatal (Figure 2). 'Not enough working opportunity' is classified as a social cause of poverty. Timmer et al. (1994), Magnet (1993), and Main (1998) argue that individual factors include alcoholism, substance abuse, or the lack of work ethic. Accordingly, 'laziness', 'inability to economize', and 'addiction' are categorized as individual types of poverty. 'Poor health' is grouped as fatal cause. In the case of the other poverty explanations like 'low income level', 'low education level', 'unemployment', and 'large family', there can be ambiguities as to whether they are structural, individual, or fatal, therefore they are excluded from this part of the analysis.

Individual
- laziness
- inability to economize
-addiction
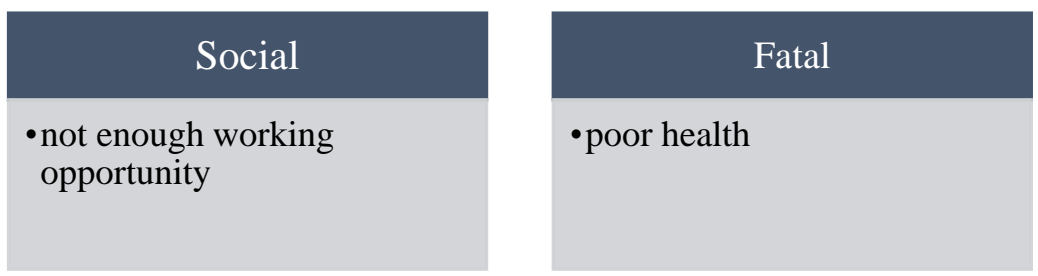

Figure 2. Categories of the perceived causes of poverty

Source. own compilation

The box plot of the groups of poverty attributions (Figure 3) shows that individual causes of poverty have the lowest mean score, while fatal ones have the highest mean score. The chart therefore highlights differences in the importance of the lay explanations of the three groups. To test weather these differences are significant, Analysis of Variance is used.

The significance value of $F$ test in the ANOVA table is 0.000 (Table 3). Therefore the hypothesis that average scores are equal across groups of poverty attribution must be rejected. The average scores highlight that individual attributions for poverty are perceived to be more important than structural ones.

Table 3.

Results of the Analysis of variance

\begin{tabular}{lccccc}
\hline & Sum of Squares & df & Mean Square & F & Sig. \\
\hline Between Groups & 115.246 & 2 & 57.623 & & \\
Within Groups & 810.782 & 142 & 5.710 & 10.092 & 0.000 \\
Total & $926, .28$ & 144 & - & & \\
\hline
\end{tabular}

Source. own compilation 


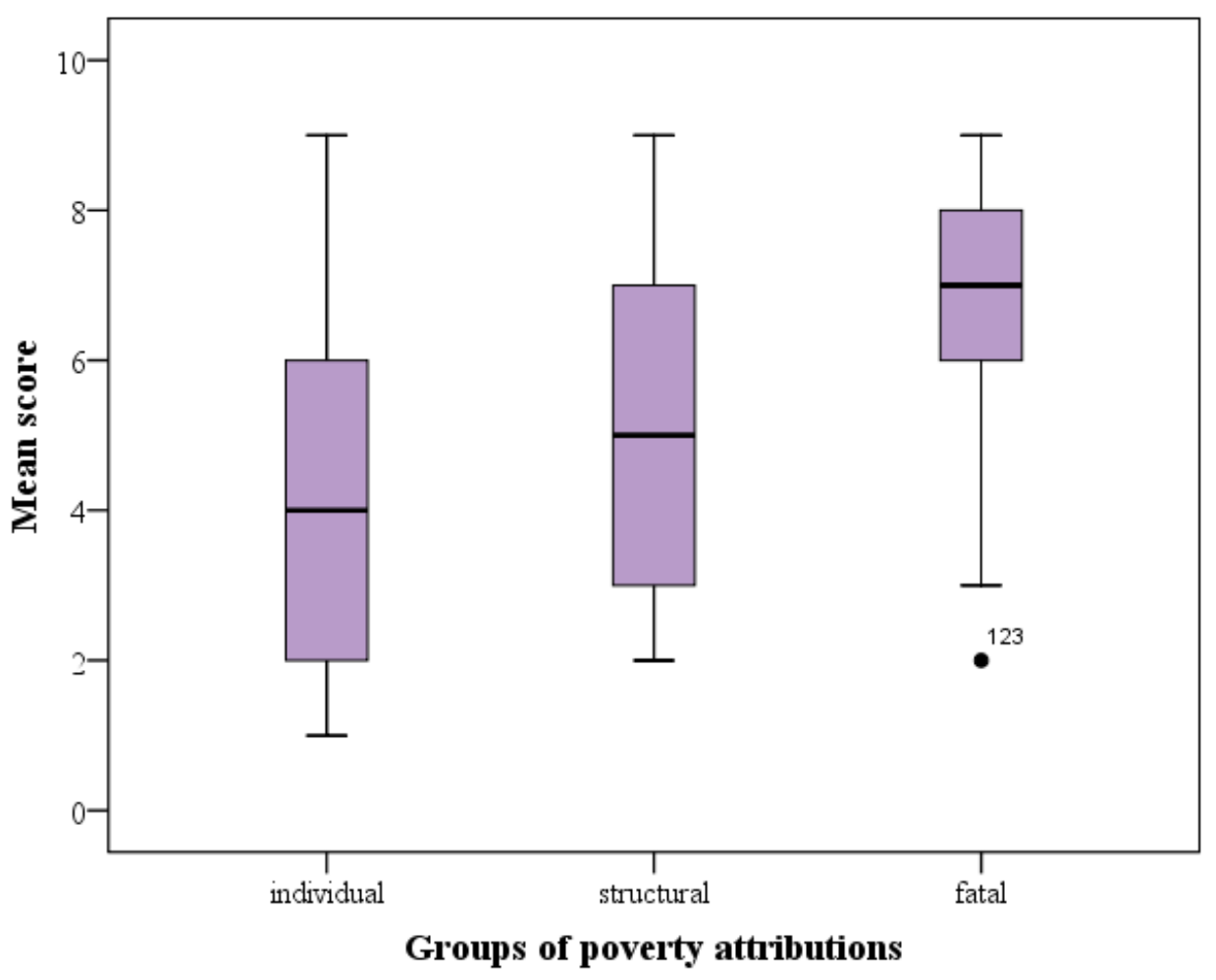

Figure 3. Box plot of the groups of poverty attributions Source. own compilation

\section{Discussion}

The hypothesis that the main lay explanations of poverty are structural in Borsod-AbaújZemplén County, Hungary, was rejected. Support for explanations which blame the individuals (like low willingness to work, addiction, or inability to economize) is stronger than support for explanations which blame structural conditions (like not enough working opportunity). In spite of the COVID-19 pandemic and the related economic and social downturn, the poor are seen by the public as being themselves responsible for their unfavourable situation.

The high support of individualistic attributions for poverty has a remarkable implication on the operation of the welfare system. Policies aiming at poverty reduction should focus more on the individual circumstances of poverty when elaborating the most effective poverty reduction strategies. The fact that the public often endorses individualistic explanations of poverty draws attention to the necessity that public aid should be made available only to the faultless poor, while the so called 'undeserving poor' shall be excluded from the support (Szalai, 2006).

A limitation of the present research is that it focuses on just one county of Hungary. It raises the question as to what extent its findings can be generalized to the whole country. Extension of the research field to more counties of Hungary would make spatial comparison possible. Finally, another promising line of research would be repeating the data collection after the pandemic to examine the effect of the end of unusual social and/or economic strains on the lay explanation of poverty.

\section{Acknowledgment}

This research was supported by the project nr. EFOP-3.6.2-16-2017-00007, titled Aspects on the development of intelligent, sustainable and inclusive society: social, technological, innovation networks in employment and digital economy. The project has been supported by 
the European Union, co-financed by the European Social Fund and the budget of Hungary.

\section{References}

De Munck, V. C. and E. J. Sobo (1988). Using Methods in the Field: A Practical Introduction and Casebook. Walnut Creek (CA) - London - New Delhi: Altamira Press, A Division of Sage Publications, Inc.

Feagin, J. R. (1975). Subordinating poor persons: Welfare and American beliefs. Englewood Cliffs, Prentice-Hall.

Furnham, A. (1982). Why are the poor with us? Explanation for poverty in Britain, British Journal of Social Psychology, 21(4), pp. 311-322. https://doi.org/10.1111/j.2044-8309. 1982.tb00553.x

Habibov, N., A. Cheung, A. Auchynnikava, A. and L. Fan (2017). Explaining support for structural attribution of poverty in post-communist countries: multilevel analysis of repeated cross-sectional data, The Journal of Sociology and Social Welfare, 44(3), pp. 173-197.

Harper, D. J. (1996). Accounting for poverty: from attribution to discourse, Journal of Community and Applied Social Psychology, 6(4), pp. 249-265.

Hunt, M. (1996). The individual, society, or both? A comparison of Black, Latino and White beliefs about the causes of poverty. Social Forces, 75, pp. 293-322. https://doi.org/10.1093/sf/75.1.293

Hunt, M. and H. E. Bullock (2016). Ideologies and Beliefs about Poverty. In: D. Brady and L. M. Burton (eds.) The Oxford Handbook of the Social Science of Poverty, pp. 93-116. New York: Oxford University Press. https://doi.org/10.1093/oxfordhb/9780199914050.013.6

Kainu, M. and A. Niemelä (2014). Attributions for Poverty in Post-Socialist Countries. Available: http://muuankarski.github.io/attributions/article2013.pdf.

Kallio, J. and M. Niemelä(2014). Who Blames the Poor? Multilevel evidence of support for and determinants of individualistic explanations of poverty in Europe, European Societies, 16(1), pp. 112-35. https://doi.org/10.1080/14616696.2013.787435

Kluegel, J. R. and E. R. Smith (1986). Social institutions and social change. Beliefs about inequality: Americans' views of what is and what ought to be. Aldine de Gruyter. https://doi .org/10.1093/sw/33.1.85-b

Kreidl, M. (2000). Perceptions of poverty and wealth in western and post-communist countries, Social Justice Research, 13, pp. 151-176.

Lepianka, D., W. Oorschot and J. Gelissen (2009). Popular Explanations of Poverty: A Critical Discussion of Empirical Research, Journal of Social Policy, 38(3), pp. 421-438. https://doi.org/10.1017/s0047279409003092

Magnet, M. (1993). The dream and the nightmare: The sixties' legacy to the underclass. William Morrow and Company, New York.

Main, T. (1998). How to think about homelessness: balancing structural and individual causes, Journal of Social Distress and the Homeless, 7(1), pp. 41-54. https://doi.org/10.1023/ a:1022966631533

Siposné Nándori, E. (2016). How did subjective well-being change in Hungary due to the economic crisis? Social Indicators Research, 126 (1), pp. 241-256. https://doi.org/10.1007/ $\underline{\text { s11205-015-0878-9 }}$ 
Siposné Nándori, E. (2021a). Changes in the Subjective Interpretation of Poverty Due to COVID-19: The Case of a Peripheral County of Hungary. 15. International Conference on Economics and Finance, April 08-09, 2021 in Athens, Greece, pp. 279-284.

Siposné Nándori, E. (2021b). Individualism or Structuralism-Differences in the Public Perception of Poverty between the United States and East-Central Europe. Journal of Poverty. Under publication. https://doi.org/10.1080/10875549.2021.1910892

Szalai, J. (2006). Poverty and the Traps of Postcommunist Welfare Reforms in Hungary: The new challenges of EU-accession, Revija Za Socijalnu Politiku, 13(3-4), pp. 309-333. https://doi.org/10.3935/rsp.v13i3.644

Timmer, D. A., D. S. Eitzen and K. D. Talley (1994). Paths to homelessness: Extreme poverty and the urban housing crisis. Westview Press, Boulder, CO. https://doi.org/10.4324 19780429301124

Van Oorschot, W. and L. Halman (2000). Blame or Fate, Individual or Social. An international comparison of popular explanations of poverty, European Societies, 2(1), pp. 1-28. https://doi.org/10.1080/146166900360701

Weller, S. C. (2007). Cultural consensus theory: applications and frequently asked questions, Field Methods, 19, pp. 339-368. https://doi.org/10.1177/1525822x07303502

Weller, S. C. and A. K. Romney (1988). Systematic data collection. Qualitative Research Methods, vol. 10, Newbury Park: Sage Publications, Inc.

Williamson, J. B. (1974). Beliefs about the motivation of poor persons and attitudes toward poverty policy, Social Problems, 21(5), pp. 634-648. https://doi.org/10.1525/sp.1974.21 $.5 .03 \mathrm{a} 00040$ 